\title{
Development of Standardized Domestic Hot Water Event Schedules for Residential Buildings
}

R. Hendron and J. Burch

Presented at Energy Sustainability 2007 Long Beach, California June 27-30, 2007

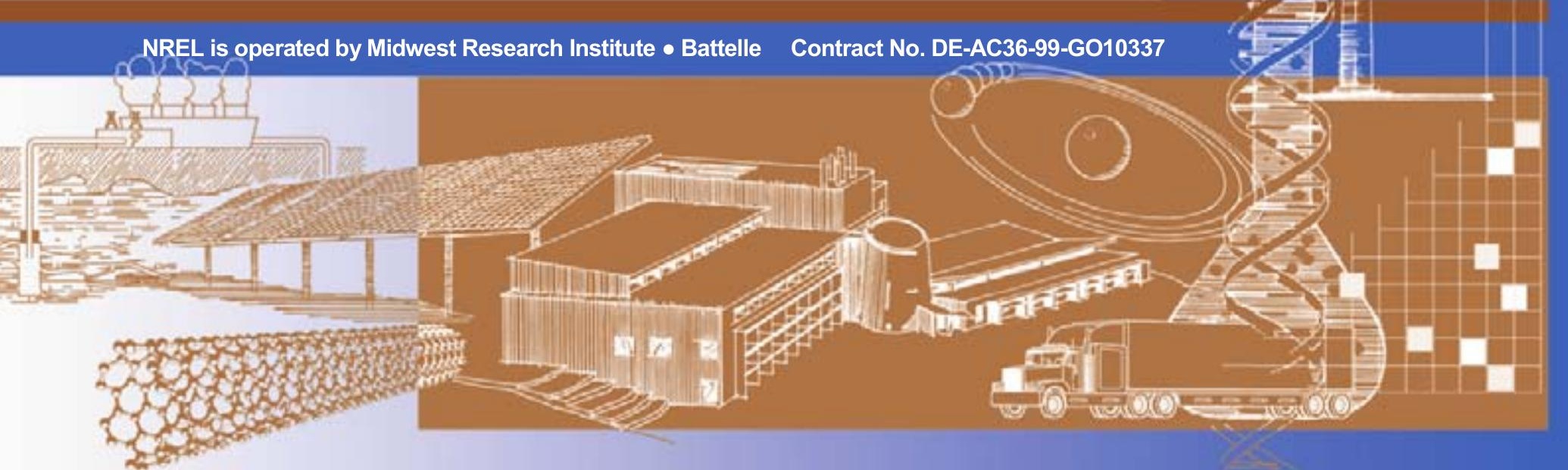




\section{NOTICE}

The submitted manuscript has been offered by an employee of the Midwest Research Institute (MRI), a contractor of the US Government under Contract No. DE-AC36-99G010337. Accordingly, the US Government and MRI retain a nonexclusive royalty-free license to publish or reproduce the published form of this contribution, or allow others to do so, for US Government purposes.

This report was prepared as an account of work sponsored by an agency of the United States government. Neither the United States government nor any agency thereof, nor any of their employees, makes any warranty, express or implied, or assumes any legal liability or responsibility for the accuracy, completeness, or usefulness of any information, apparatus, product, or process disclosed, or represents that its use would not infringe privately owned rights. Reference herein to any specific commercial product, process, or service by trade name, trademark, manufacturer, or otherwise does not necessarily constitute or imply its endorsement, recommendation, or favoring by the United States government or any agency thereof. The views and opinions of authors expressed herein do not necessarily state or reflect those of the United States government or any agency thereof.

Available electronically at http://www.osti.gov/bridge

Available for a processing fee to U.S. Department of Energy and its contractors, in paper, from:

U.S. Department of Energy

Office of Scientific and Technical Information

P.O. Box 62

Oak Ridge, TN 37831-0062

phone: 865.576 .8401

fax: 865.576 .5728

email: mailto:reports@adonis.osti.gov

Available for sale to the public, in paper, from:

U.S. Department of Commerce

National Technical Information Service

5285 Port Royal Road

Springfield, VA 22161

phone: 800.553 .6847

fax: 703.605.6900

email: orders@ntis.fedworld.gov

online ordering: http://www.ntis.gov/ordering.htm 


\section{DEVELOPMENT OF STANDARDIZED DOMESTIC HOT WATER EVENT SCHEDULES FOR RESIDENTIAL BUILDINGS}

\author{
Robert Hendron \\ National Renewable Energy Laboratory \\ Golden, CO
}

\author{
Jay Burch \\ National Renewable Energy Laboratory \\ Golden, CO
}

\begin{abstract}
The Building America Research Benchmark is a standard house definition created as a point of reference for tracking progress toward multi-year energy savings targets. As part of its development, the National Renewable Energy Laboratory (NREL) has established a set of domestic hot water events to be used in conjunction with sub-hourly analysis of advanced hot water systems. In certain applications (including analysis of recirculation loops, distribution losses, tankless gas water heaters, and solar hot water systems with load-side heat exchangers) energy use can be strongly affected by event flow rate, duration, frequency, clustering, and time of occurrence. High-level constraints on mains temperature and average daily hot water use, along with detailed event characteristics derived from past research and a software tool developed by Kassel University in Germany, were used to generate hot water events over one year for houses of different sizes in various locations. The events were established in 6-min increments for showers, baths, sinks, clothes washers, and dishwashers. Flow rates and times of occurrence varied randomly based on specified probability distributions. The final event schedules reflected the same daily variability as an actual household, thereby providing more realism to energy simulations involving advanced water heating systems.
\end{abstract}

\section{NOMENCLATURE}

$\begin{array}{ll}\text { day\# } & \text { Julian day of the year (1-365) } \\ \text { lag } & 35-1.0\left(\mathrm{~T}_{\text {amb,avg }}-44\right) \\ \mathrm{N}_{\mathrm{br}} & \text { Number of bedrooms } \\ \text { offset } & 6^{\circ} \mathrm{F} \\ \text { ratio } & 0.4+0.01\left(\mathrm{~T}_{\text {amb,avg }}-44\right) \\ \mathrm{T}_{\text {mains }} & \text { Mains (supply) temperature to domestic hot } \\ & \left.\text { water tank ( }{ }^{\circ} \mathrm{F}\right) \\ \mathrm{T}_{\text {amb,avg }} & \text { Annual average ambient air temperature }\left({ }^{\circ} \mathrm{F}\right) \\ \mathrm{V}_{\mathrm{d} \text {,avg }} & \text { Annual average volume of hot water (gal) } \\ \mathrm{V}_{\mathrm{d}, \text { wk-day }} & \text { Daily volume of hot water: weekday (gal) } \\ \mathrm{V}_{\mathrm{d}, \text { wk-end }} & \text { Daily volume of hot water: weekend (gal) } \\ \mathrm{V}_{\mathrm{h}} & \text { Hourly volume of hot water (gal) }\end{array}$

$\begin{array}{ll}\Delta \mathrm{T}_{\text {amb,max }} & \begin{array}{l}\text { Maximum difference between monthly } \\ \text { average ambient temperatures }\left({ }^{\circ} \mathrm{F}\right)\end{array} \\ \Delta \mathrm{t}_{\text {draw }} & \text { Hot water draw duration }(\mathrm{sec}) \\ \Delta \mathrm{t}_{\text {time-step }} & \text { Simulation time step }(\mathrm{sec}) \\ \mu_{\mathrm{fr}} & \text { Average event flow rate }(\mathrm{l} / \mathrm{hr}) \\ \sigma_{\mathrm{fr}} & \text { Flow rate standard deviation }(\mathrm{l} / \mathrm{hr})\end{array}$

\section{INTRODUCTION}

The Building America Program sponsored by the U.S. Department of Energy (DOE) has defined a series of climatedependent whole-house energy savings goals (e.g., achieve $40 \%$ savings in hot/dry climates by 2007), eventually leading to cost-neutral zero-energy homes in all climates by 2020 . Tracking progress toward these goals necessitates the use of a "Benchmark" house. The Benchmark defines climatedependent building characteristics and operational schedules, including those for domestic hot water (DHW) use [1]. The DHW time-of-day use profiles are based in part on the EndUse Load and Consumer Assessment Program (ELCAP) study conducted in the Pacific Northwest [2], and the average daily volume is a function of the number of bedrooms, the climate, and the season.

However, DHW use is quite complex, involving a spectrum of users and applications with varying inlet temperatures, volumes, flow rates, and timing. The major residential DHW end uses include sinks, showers, baths, dishwashers, and clothes washers, which are "discrete events" initiated by occupants. These events each have a characteristic range of flow rates and durations (or volumes), as in [3]. DHW use is also idiosyncratic by household. Average daily volume usage varies between households by an order of magnitude ( $\sim 50$ 1/day to $\sim 5001 /$ day), depending on occupant density and their habits [4]. Time-of-use varies widely also. For each household, there is both a deterministic component and a random component to DHW use. People tend to take showers, shave, clean dishes, etc. at more-or-less the same time each day, albeit somewhat differently on work-days vs. non-work days. On the other hand, DHW usage varies 
stochastically with all the complexities of modern life, including somewhat random unoccupied/vacation periods, varying number of showers/person/day, varying number of loads of clothes and cycle temperatures, varying use of dishwashers, somewhat varying duration and flow rates for sink and shower events, and so on.

To predict DHW energy consumption using a simulation, an exogenous hot water draw profile must be chosen. However, the level of detail needed in the draw profile depends on the study objectives, as described in Table 1 . The key draw parameters are the average daily volume, draw flow rates, timing of draws, and variability in draw patterns. When comparing storage water heaters without concern for runout (i.e., failure to deliver hot-enough water), the only parameter of any significance is the daily draw volume; draw flow rate and timing are mostly irrelevant. However, the performance of some DHW system components can also depend on the draw flow rate, timing, and/or day-to-day variability in load volume. The performance of a solar water heater (SWH) is sensitive to general load timing (especially integral-collector-storage systems) and to day-to-day variability (because of storage dynamics). In addition, the performance of a SWH with a load-side heat exchanger depends significantly on the flow rates of the hot water draws [5]. The analysis of losses from DHW distribution sub-systems also depends on the time between draws, as in [6]. For these cases it is necessary to specify a statistically realistic distribution for the key variables.

Most previous DHW system studies neglect variability and have employed relatively simple draw profiles. Timing is ignored in [7]. The schedule used in the U.S. for water heater testing [8] is defined as six draws of 11-gallons each, one hour apart, with a flow rate of $3 \mathrm{gpm}$. This schedule should be used only when $\mathrm{V}_{\mathrm{d} \text {,avg }}$ is the only significant system variable, as with conventional storage water heaters. A simple 24-hour "double-humped" schedule with the flow rate set to $V_{h}$ /hour is used for annual solar hot water system ratings by the Solar Rating and Certification Corporation (SRCC) [9]. There are at least four studies that have derived ensemble long-term averages for $V_{h}[10]$, but there are very few differences among them. These hourly schedules work well if volume and timing are of concern, but flow rate and variability are not (as when comparing solar systems without load-side heat exchangers). To incorporate flow rate dependence, a constrained schedule was developed in [11]. Three flow rates were defined: $0.5 \mathrm{gpm}$ (representing sink usage), $1.5 \mathrm{gpm}$ (representing showers and dishwashers), and $2.5 \mathrm{gpm}$ (representing baths and clothes washers). Two schedules ("yuppie" and "nuclear family") were then assembled by defining a set of events (one of the three flow rates, start time, and duration of draw) subject to the following constraints: $V_{\mathrm{d} \text {,avg }}=62 \mathrm{gal} / \mathrm{day}$; the flow rate distribution roughly matches that observed in a previous 12house study [12]; there are weekday and weekend day types, with $\mathrm{V}_{\text {d,wk-end }}=1.45 \mathrm{~V}_{\text {d,wk-day }}$; and modulo $\left(\Delta \mathrm{t}_{\text {draw }}, \Delta \mathrm{t}_{\text {time-step }}\right)=0$. Similar profiles were developed in [13]. However, such profiles do not incorporate day-to-day variability and are misleading in predicting absolute performance of or optimizing SWH systems. The difficulty of defining "realistic" draw profiles led one group to incorporate houseyears of raw data as a draw profile option [14]. This latter approach is cumbersome and begs the question of how representative those arbitrarily-chosen 10 houses are.

The technical objective for the present study is to use published data related to average water volume, timing, variability, and frequency from previous studies to constrain otherwise randomly generated hot water events that can be used for all of the applications described in Table 1 .

\section{Table 1 Study Objective vs Draw Characteristics} Needed in the Draw Profile: Examples

\begin{tabular}{|c|c|}
\hline Study Objective & $\begin{array}{c}\text { Draw Characteristics } \\
\text { Needed }\end{array}$ \\
\hline $\begin{array}{l}\text { Comparing storage } \\
\text { water heater energy }^{a}\end{array}$ & Daily volume only \\
\hline $\begin{array}{l}\text { Sizing of storage water } \\
\text { heater }^{\text {b }}\end{array}$ & $\begin{array}{l}\text { Timing, volume ("worst" draw } \\
\text { sequence) }\end{array}$ \\
\hline $\begin{array}{l}\text { Compare SWH with } \\
\text { load-side heat } \\
\text { exchanger }\end{array}$ & $\begin{array}{l}\text { Volume, flow rate, timing, } \\
\text { and variability }\end{array}$ \\
\hline $\begin{array}{l}\text { Minimize distribution } \\
\text { network losses }^{d}\end{array}$ & Volume, flow rate and timing \\
\hline 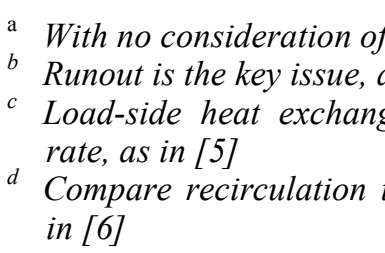 & $\begin{array}{l}\text { unout, as in [7] } \\
\text { in [15] } \\
r \text { effectiveness depends on flow } \\
\text { pes, minimize stranded water, as }\end{array}$ \\
\hline
\end{tabular}

\section{TECHNICAL APPROACH}

\section{Current Benchmark Approach}

Until 2007, the Building America Benchmark used a relatively simple approach to defining hot water use. An essentially fixed daily volume was used for each of the 365 days in a year, with adjustments to the hot water use for showers, baths, and sinks, to reflect seasonal variations in mains temperature assuming a constant $120^{\circ} \mathrm{F}$ hot water supply temperature. Colder mains temperatures in winter would result in higher hot water use to maintain the same assumed mixed temperature of $105^{\circ} \mathrm{F}$ at the fixture. The mains temperature was calculated using Equation 1, which was developed based on a correlation derived from measured field data. The development of this equation is discussed further in [1]. An example mains temperature profile for Chicago is shown in Fig. 1.

$$
\begin{gathered}
\mathrm{T}_{\text {mains }}=\left(\mathrm{T}_{\mathrm{amb}, \mathrm{avg}}+\text { offset }\right)+\text { ratio } *\left(\Delta \mathrm{T}_{\mathrm{amb}, \max } / 2\right) * \\
\sin (0.986 *(\text { day } \#-15-\text { lag })-90)
\end{gathered}
$$




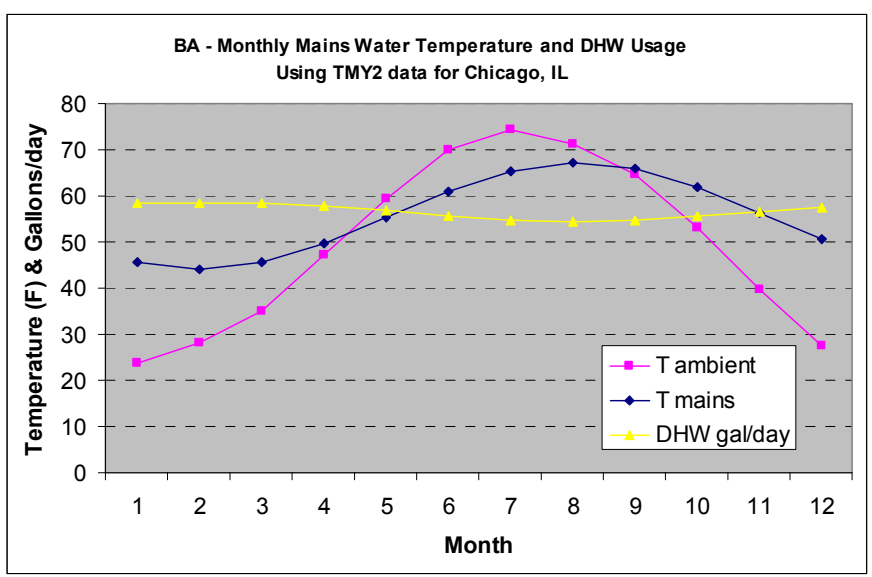

Fig. 1 Seasonal mains temperature profile for Chicago

The daily average hot water use for the Benchmark was established as a linear function of the number bedrooms, which served as a surrogate variable for number of occupants. The relationship between bedrooms and occupants was based on the DOE's 2001 Residential Energy Consumption Survey (RECS) [16]. Baths and showers were treated as one end-use until 2007, when they were split as part of this project because of their very different hourly profiles. Average daily volume for each end-use was established based on a survey of recent hot water studies and other authoritative references [4, 17-22]. These Benchmark daily hot water volumes are summarized in Table 2 .

Table 2 Benchmark water temperature and volume for each DHW end-use

\begin{tabular}{|c|c|c|}
\hline End Use & $\begin{array}{c}\text { End-Use } \\
\text { Water } \\
\text { Temperature }\end{array}$ & Water Usage \\
\hline $\begin{array}{l}\text { Clothes } \\
\text { Washer }\end{array}$ & $\begin{array}{l}120^{\circ} \mathrm{F} \\
(\mathrm{Hot})\end{array}$ & $\begin{array}{c}7.5+2.5 \times \mathrm{N}_{\mathrm{br}} \text { gal } / \text { day } \\
\text { (Hot Only) }\end{array}$ \\
\hline Dishwasher & $\begin{array}{l}120^{\circ} \mathrm{F} \\
(\mathrm{Hot})\end{array}$ & $\begin{array}{c}2.5+0.833 \times \mathrm{N}_{\mathrm{br}} \text { gal/day } \\
\text { (Hot Only) }\end{array}$ \\
\hline Shower & $\begin{array}{l}105^{\circ} \mathrm{F} \\
\text { (Mixed) }\end{array}$ & $\begin{array}{c}14.0+4.67 \times \mathrm{N}_{\mathrm{br}} \text { gal/day } \\
(\text { Hot }+ \text { Cold })\end{array}$ \\
\hline Bath & $\begin{array}{l}105^{\circ} \mathrm{F} \\
\text { (Mixed) }\end{array}$ & $\begin{array}{c}3.5+1.17 \times \mathrm{N}_{\text {br gal }} / \mathrm{day} \\
(\text { Hot }+ \text { Cold })\end{array}$ \\
\hline Sinks & $\begin{array}{l}105^{\circ} \mathrm{F} \\
\text { (Mixed) }\end{array}$ & $\begin{array}{c}12.5+4.16 \times \mathrm{N}_{\mathrm{br}} \text { gal/day } \\
(\text { Hot }+ \text { Cold })\end{array}$ \\
\hline
\end{tabular}

A whole-house normalized DHW hourly profile was specified based on [23], and is shown in Fig. 2. More detailed end-use hourly profiles for clothes washers and dishwashers were established based on the ELCAP study [2]. A single hourly profile was used for all other end-uses, calculated by subtracting the clothes washer and dishwasher profiles from the combined hot water profile, assuming a typical 3-bedroom house in Memphis.

In most cases this level of detail was sufficient for accurate energy analysis of hot water systems. As more advanced techniques for reducing water heating energy became more commonplace in the quest for affordable Zero Energy Homes, it was clear that the Benchmark DHW specifications were overly simplistic and would not produce accurate results in many cases. However, because the BA Benchmark represented the best available information that we could find on average water use, we decided to use the highlevel parameters established for the Benchmark (hourly profiles, average daily volume) as constraints on the more detailed event schedules that we developed for this project.

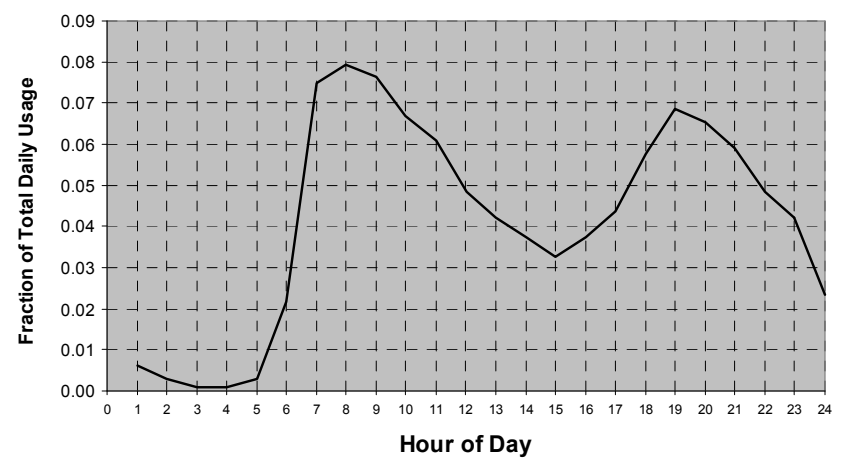

Fig. 2 Combined domestic hot water use profile for the Benchmark, representing average use

\section{Drivers of DHW Events}

The most important driver of hot water events is occupant behavior. Differing habits among individuals, along with random variations for the same individuals, combine to produce highly variable patterns within a specific household. It is not our intent to capture family-to-family differences in behavior for this project, but simply the variability for a typical family. The randomness of occupant behavior can best be duplicated using software that uses a random number generator driven by realistic probability distributions and other high-level constraints established for the Benchmark.

Other drivers of event schedules are more predictable. The number of occupants is assumed to have a linear effect on total hot water use, as discussed in the previous section. This variable primarily affects frequency of events, assuming the typical behavior of each family member is about the same, including average event timing, duration, and flow rate. It can be argued that additional family members beyond the first two are likely to be children and may use less hot water, but data from the 1997 RECS [18] indicate that the relationship between average number of occupants and average hot water use is fairly linear (Fig. 3).

Climate and season also affect event schedules indirectly through mains temperature, as discussed earlier. The higher the mains temperature, the smaller the flow rate of hot water necessary to obtain the desired mixed temperature for enduses such as showers, baths, and sinks. Our assumption is that most common clothes washers and dishwashers do not adjust the hot water flow rate or volume based on the cold water temperature, though we recognize that many advanced clothes washers control the mixed water temperature using a thermostatic control valve. Dishwashers typically rely on hot water only, which is raised to a higher temperature by an internal heater. Some references suggest there is seasonality to the frequency of hot water events, but that possible relationship was not addressed by this study.

Clothes washer and dishwasher event characteristics are strongly influenced by the efficiency of appliances present in 
the house being analyzed. Most efficient appliances reduce energy consumption by reducing the amount of water necessary to wash the dishes or clothes, by either reducing the number of cycles or using less water for each cycle. Usually, this results in shorter event durations. Alternate control types and adaptive temperature/load size features can also affect the event characteristics in many different ways. Because our focus was on developing standard event schedules, and because of the unlimited possibilities for clothes washer and dishwasher events, we assumed typical appliance characteristics and left it to the analyst to make the necessary adjustments based on actual appliance features.

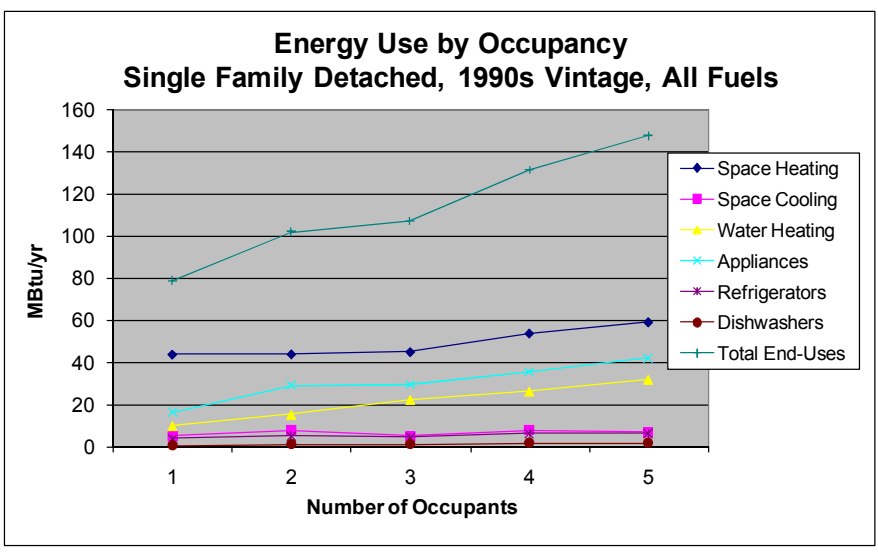

Fig. 3 Relationship between number of occupants and energy use for major end-uses based on the 1997 RECS

The effect of hot water setpoints above $120^{\circ} \mathrm{F}$ were not examined as part of this study because water supplied at such elevated temperatures poses a significant risk of scalding and is usually not recommended for residential systems. For solar storage tanks that supply hot water at temperatures up to $160^{\circ} \mathrm{F}$, the volume and flow rate of hot water events in this study should be interpreted as hot water tempered to $120^{\circ} \mathrm{F}$ using either a tempering valve or a second storage tank.

Finally, a very important driver of event duration is the magnitude of hot water distribution losses. If the distribution system has long pipe runs, oversized pipe diameters, or large pipe losses upstream of a fixture, it is likely that the user will need to wait a significant length of time before hot water arrives at the fixture. In many cases this extends the duration of the hot water event, but not always. Appliance hot water use is typically unaffected by distribution losses, and many people will begin washing their hands before hot water arrives at the faucet. Another complication is that the event schedules themselves have a large effect on the distribution losses, making the analysis an iterative process. Because these interactions are very complex, we decided to postpone the inclusion of distribution losses in the development of event schedules until the next phase of this project.

\section{Software}

The event schedules were generated using a software tool called DHWcalc developed by the solar energy research group at Kassel University in Germany [24]. The software can be downloaded at no charge from the University's website (www.solar.uni-kassel.de). DHWcalc generates random event schedules based on hourly profiles, average event characteristics, average daily volumes, and other constraints entered by the user. Events have a fixed duration, which must be a multiple of the selected time step. Event flow rate, and consequently event volume, varies randomly around an average value $\left(\mu_{\mathrm{fr}}\right)$ based on a standard deviation $\left(\sigma_{\mathrm{fr}}\right)$ entered by the user. Of course in a real household, it is event duration that varies much more than flow rate, but it would be impossible to have highly variable durations without extremely small time steps. An hourly probability distribution is entered into the software using a step function. The probability distribution is tuned automatically by the software to account for user-specified variations in seasonal, weekend/weekday, and holiday event frequency.

\section{Assumptions and Inputs}

Although 1-min time-steps are optimal for the purpose of specifying realistic event durations (Table 3), longer 6-min time steps with clustered sink events are actually more realistic than independent 1-minute events, because in many home situations (such as washing hands before dinner, rinsing dishes, getting ready for school/work) there is a tendency for a series of sink events to occur at about the same time (see Fig. 4). Either profile is possible depending on the behavior of the occupants, but based on our examination of data collected for approximately 1200 households by the American Water Works Association (AWWA) [25], clustered sink events appear to be more common (see Fig. 5). This conclusion is also supported by our recent monitoring activities in Building America houses. Fig. 6 shows the clustering of what we believe are sink events on a representative day in January for a Building America house near Denver, Colorado. In the end, 6min time steps were chosen for this project because they offered the greatest overall realism.

Table 3 DHW Event Characteristics in 1-Min Increments for a Three-Bedroom House

\begin{tabular}{|c|c|c|c|c|c|}
\hline & $\begin{array}{l}\text { Clothes } \\
\text { Washer }\end{array}$ & $\begin{array}{c}\text { Dish- } \\
\text { washer }\end{array}$ & Shower $^{a}$ & Bath $^{a}$ & $\operatorname{Sin}^{a}$ \\
\hline $\begin{array}{l}\mathrm{V}_{\mathrm{d}, \text { avg }} \text { in liters } \\
\text { (gal) }\end{array}$ & $\begin{array}{c}57 \\
(15)\end{array}$ & $\begin{array}{l}19 \\
(5)\end{array}$ & $\begin{array}{l}106 \\
(28)\end{array}$ & $\begin{array}{l}26 \\
(7)\end{array}$ & $\begin{array}{c}95 \\
(25)\end{array}$ \\
\hline $\begin{array}{l}\mu_{\mathrm{fr}} \text { in } \mathrm{l} / \mathrm{hr} \\
\text { (gal/min) }\end{array}$ & $\begin{array}{c}319 \\
(1.4)\end{array}$ & $\begin{array}{l}242 \\
(1.1)\end{array}$ & $\begin{array}{c}479 \\
(2.1)\end{array}$ & $\begin{array}{l}958 \\
(4.2)\end{array}$ & $\begin{array}{c}161 \\
(0.7)\end{array}$ \\
\hline $\begin{array}{l}\sigma_{\text {fr }} \text { in } l / h r \\
\text { (gal/min) }\end{array}$ & $\begin{array}{c}160 \\
(0.7)\end{array}$ & $\begin{array}{c}36 \\
(0.2)\end{array}$ & $\begin{array}{l}239 \\
(1.1)\end{array}$ & $\begin{array}{l}239 \\
(1.1)\end{array}$ & $\begin{array}{l}241 \\
(1.1)\end{array}$ \\
\hline Duration (min) & 10 & 8 & 8 & 5 & 1 \\
\hline $\begin{array}{l}\text { Weekend/ } \\
\text { Weekday ratio }\end{array}$ & $115 \%$ & $115 \%$ & $115 \%$ & $300 \%$ & $115 \%$ \\
\hline Events/day & 1.07 & 0.59 & 1.66 & 0.324 & 35.5 \\
\hline Events/year & 392 & 215 & 606 & 118 & 12958 \\
\hline
\end{tabular}

Several adjustments to the 1-min event characteristics were necessary to make the other four end-uses compatible with 6-min time steps. The duration of showers (8-min) and baths (5-min) were changed to 6-min, while keeping the flow 
rate and average daily volume the same. As a result, event frequency was altered to some extent for the 6-min time-steps. Clothes washer event duration was changed from $10 \mathrm{~min}$ to 12 min, and dishwasher event duration was changed from 8 min to $6 \mathrm{~min}$. Because the annual number of clothes washer and dishwasher events were defined in the Benchmark, we adjusted the flow rates to force the daily volumes to remain the same.

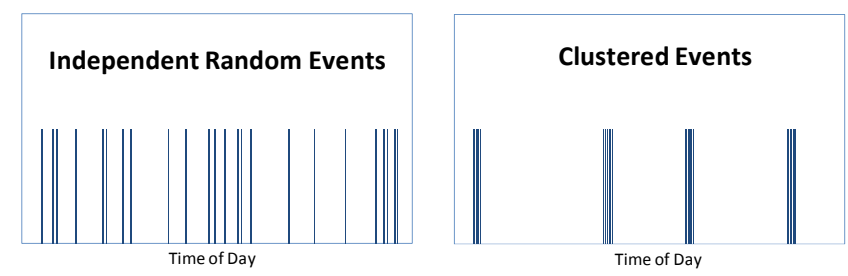

Fig. 4 Comparison of 24 independent random 1-minute events to 4 randomly distributed 6 -minute clusters

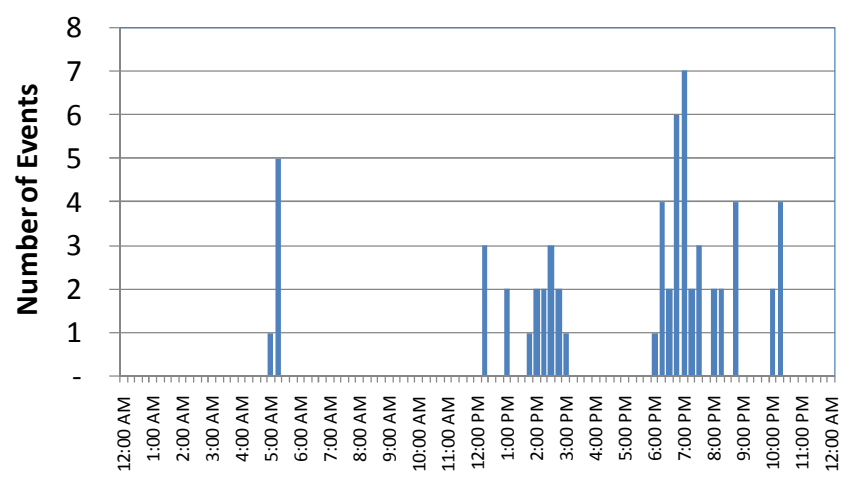

Fig. 5 Clustering of faucet events (hot and cold) in 15minute intervals for a household with two occupants [25]

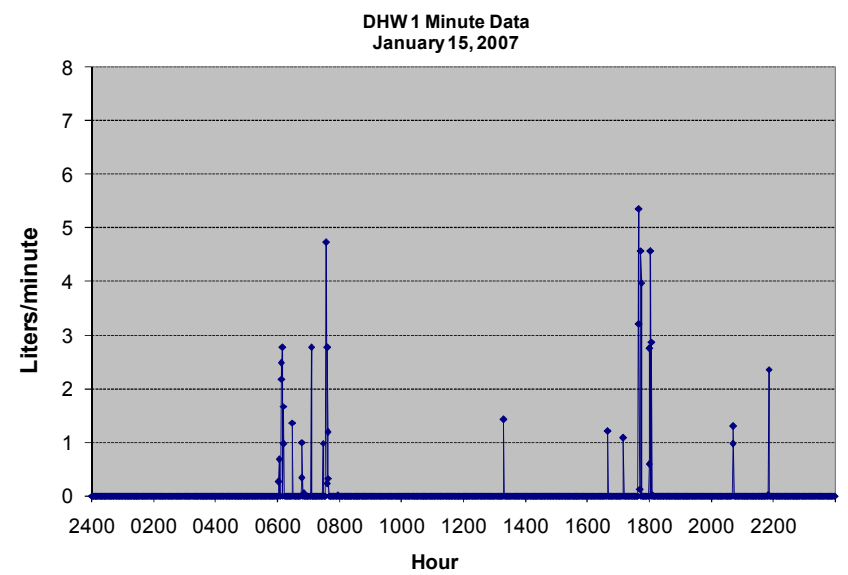

Fig. 6 Clustering of likely faucet events (hot water only) for a Building America house with three occupants

The final event characteristics developed for Building America using 6-min time-steps are shown in Table 4. Note that for the purpose of DHWcalc analysis, sinks, baths, and shower events include both hot and cold water. The use of combined hot and cold water volume allows climatedependent variations based on mains temperature to be ignored during the initial stages of analysis, avoiding the necessity to run DHWcalc for many different locations. A spreadsheet was designed to automatically extract the hot water flow from the DHWcalc outputs based on a userselected typical meteorological year (TMY2) site [26]. Seasonal variations in hot water use are also calculated automatically by the spreadsheet.

Table 4 DHW Event Characteristics in 6-Min Increments for a Three-Bedroom House

\begin{tabular}{|c|c|c|c|c|c|}
\hline & $\begin{array}{l}\text { Clothes } \\
\text { Washer }\end{array}$ & $\begin{array}{l}\text { Dish- } \\
\text { washer }\end{array}$ & Shower ${ }^{b}$ & Bath $^{\text {b }}$ & Sink \\
\hline $\begin{array}{l}\mathrm{V}_{\mathrm{d}, \text { avg }} \text { in liters } \\
\text { (gallons) }\end{array}$ & $\begin{array}{l}57 \\
(15)\end{array}$ & $\begin{array}{l}19 \\
(5)\end{array}$ & $\begin{array}{l}106 \\
(28)\end{array}$ & $\begin{array}{l}26 \\
(7)\end{array}$ & $\begin{array}{c}95 \\
(25)\end{array}$ \\
\hline $\begin{array}{l}\mu_{\mathrm{fr}} \text { in } \mathrm{l} / \mathrm{hr} \\
\text { (gal/min) }\end{array}$ & $\begin{array}{l}266 \\
(1.2)\end{array}$ & $\begin{array}{l}323 \\
(1.4)\end{array}$ & $\begin{array}{l}479 \\
(2.1)\end{array}$ & $\begin{array}{l}958 \\
(4.2)\end{array}$ & $\begin{array}{l}161 \\
(0.7)\end{array}$ \\
\hline $\begin{array}{l}\sigma_{\text {fr in } \mathrm{l} / \mathrm{hr}} \\
\text { (gal/min) }\end{array}$ & $\begin{array}{l}133 \\
(0.6)\end{array}$ & $\begin{array}{c}48 \\
(0.2)\end{array}$ & $\begin{array}{l}239 \\
(1.1)\end{array}$ & $\begin{array}{l}239 \\
(1.1)\end{array}$ & $\begin{array}{l}241 \\
(1.1)\end{array}$ \\
\hline Duration (mins) & 12 & 6 & 6 & 6 & 6 \\
\hline $\begin{array}{l}\text { Weekend/ } \\
\text { Weekday ratio }\end{array}$ & $115 \%$ & $115 \%$ & $115 \%$ & $300 \%$ & $115 \%$ \\
\hline Events/day & 1.07 & 0.59 & 2.21 & 0.27 & 5.9 \\
\hline Events/year & 392 & 215 & 808 & 99 & 2160 \\
\hline
\end{tabular}

${ }^{\text {b }}$ Flow rates and volumes include both hot and cold water

Average daily volume was constrained to match the Benchmark values shown in Table 2 for a three-bedroom house. For clothes washers and dishwashers, the hourly profiles were taken from the Benchmark, and the event frequencies were based on the corresponding DOE appliance rating procedures [27, 28]. Average clothes washer and dishwasher event durations were estimated by NREL based on engineering judgment and some limited appliance testing. Flow rates were then calculated based on event frequency, duration, and average daily volume. For showers, baths, and sinks, the hourly profiles and average event durations and flow rates were estimated based on the AWWA study [25]. Event frequencies were then calculated based on flow rate, duration, and daily volume. It should be noted that the AWWA data included all water events (hot, cold, and mixed), and individual end-use events were disaggregated statistically instead of being measured directly. As a result, the data from that study must be used with caution.

An assumption was made that a typical home is unoccupied 14 days each year (one week in June and one week in December), and that no events occur on those days. This number of unoccupied days (or holidays) was calculated based on the average percent of days with no toilet draws in the AWWA study. The ratio of average daily volume on weekends compared to weekdays was also based on the AWWA study. Only bath events were significantly more or less common on weekends, occurring approximately three times more often than on weekdays. Finally, standard deviation of event volume for each end-use was derived from 
the water use data in the AWWA study and was intended to be representative of an average family. These values may be somewhat smaller than the standard deviation for hot water alone, because there is likely to be some variation in the enduse temperature superimposed on the variations in duration and flow rate that are reflected in the AWWA data.

\section{RESULTS}

\section{Event Schedules}

The final event schedules generated for two, three, and four-bedroom houses have been posted in spreadsheet format on the Building America performance analysis website (www.eere.energy.gov/buildings/building_america/pa resourc es.html). The nearest TMY2 site must be selected in the tab labeled "Inputs." In most cases the combined event schedule is sufficient for the analysis of DHW systems, but individual end-use events are also provided in case the events must be associated with specific fixtures, as would be the case when hot water distribution losses are analyzed. The annual events are split into 12 months because the 2003 version of Microsoft Excel does not allow 87,000 rows. This limitation will be lifted in the 2007 release of Excel.

An example set of events for a three-bedroom house in Las Vegas is shown in Fig. 7. The graph covers the period of March 1-8. Clustering of events and variations in event volume were visible, as we would expect in an actual household.

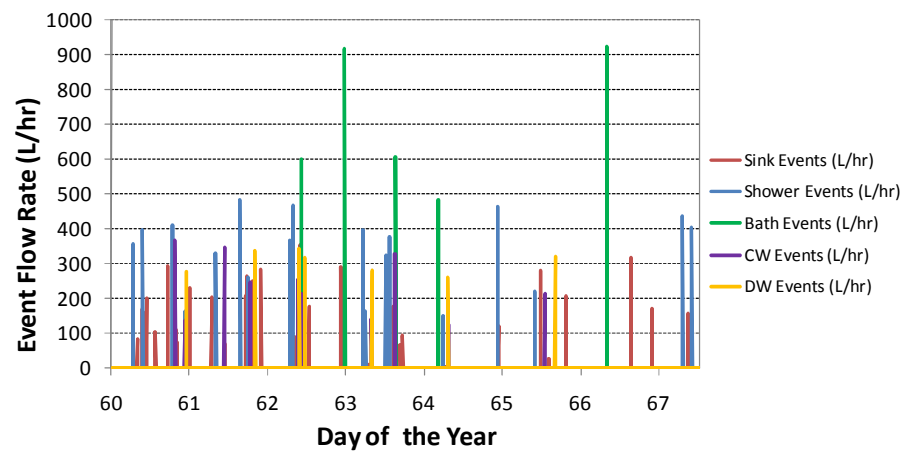

Fig. 7 Final event schedule for the time period March 1-8 for a three-bedroom house in Las Vegas

\section{Validation}

Once the event schedules were generated, we compared the output event characteristics with the inputs entered into the DHWcalc software to make sure the results were consistent. Table 5 summarizes the validation of several important event characteristics for the five end-uses, including average flow rate $\left(\mu_{\mathrm{fr}}\right)$, standard deviation of flow rate $\left(\sigma_{\mathrm{fr}}\right)$, event frequency, and annual water use. Most parameters matched up very well except for $\sigma_{\text {fr }}$, which was smaller than we specified for all five end-uses. In other words, there was not as much event-to-event variability as we wanted. Another concern was that sink event characteristics were not consistent with the input parameters, except for the annual flow volume. We have contacted the creators of DHWcalc to find the cause of these discrepancies and to make corrections if warranted.
The day-to-day standard deviation in total hot water use is about $60 \%$ over the course of a year. An illustration of this daily variation for the month of June is shown in Fig. 8. This result is somewhat less than the standard deviation of $71 \%$ calculated based on the AWWA data for almost 1200 houses. However, because the AWWA data includes both hot and cold water use, it is unclear how this would translate to hot water alone. Our supposition is that the variability of hot water would be higher for the same reasons discussed earlier in the context of event volume. The AWWA data is also for only 4 weeks of the year, usually 2 weeks in summer and 2 weeks in winter. It seems likely that the variability for a whole year would be smaller than for 2 weeks at the extremes. Another data point is offered by four occupied Building America houses with direct monitoring of DHW usage. The average day-to-day standard deviation for these four houses was $60 \%$, which happens to be the same as our event schedules. A third study [12] of twelve houses concluded that day-to-day standard deviation was $33 \%$ for weekdays and $40 \%$ for weekends, suggesting that daily volume is significantly less variable than the daily sum of event volumes for this project. Overall, we are comfortable that our day-to-day variability is reasonable compared to the average of other studies.

Table 5 Validation of key event schedule characteristics for a three-bedroom house

\begin{tabular}{|l|c|c|c|c|c|}
\hline & $\begin{array}{c}\text { Clothes } \\
\text { Washer }\end{array}$ & $\begin{array}{c}\text { Dish- } \\
\text { washer }\end{array}$ & Shower $^{\mathbf{a}}$ & Bath $^{\mathbf{a}}$ & Sink $^{\mathbf{a}}$ \\
\hline $\begin{array}{l}\text { Input } \mu_{\mathrm{fr}}, 1 / \mathrm{hr} \\
\text { (gal/min) }\end{array}$ & $\begin{array}{c}266 \\
(1.17)\end{array}$ & $\begin{array}{c}323 \\
(1.42)\end{array}$ & $\begin{array}{c}479 \\
(2.11)\end{array}$ & $\begin{array}{c}958 \\
(4.22)\end{array}$ & $\begin{array}{c}161 \\
(0.71)\end{array}$ \\
$\begin{array}{l}\text { Output } \mu_{\mathrm{fr}}, \mathrm{l} / \mathrm{hr} \\
\text { (gal/min) }\end{array}$ & $\begin{array}{c}268 \\
(1.18)\end{array}$ & $\begin{array}{c}324 \\
(1.43)\end{array}$ & $\begin{array}{c}484 \\
(2.13)\end{array}$ & $\begin{array}{c}974 \\
(4.29)\end{array}$ & $\begin{array}{c}212 \\
(0.93)\end{array}$ \\
\hline $\begin{array}{l}\text { Input } \sigma_{\mathrm{fr}}, \mathrm{l} / \mathrm{hr} \\
\text { (gal/min) }\end{array}$ & $\begin{array}{c}133 \\
(0.59)\end{array}$ & $\begin{array}{c}48 \\
(0.21)\end{array}$ & $\begin{array}{c}239 \\
(1.05)\end{array}$ & $\begin{array}{c}239 \\
(1.05)\end{array}$ & $\begin{array}{c}241 \\
(1.06)\end{array}$ \\
$\begin{array}{l}\text { Output } \sigma_{\mathrm{fr}}, \mathrm{l} / \mathrm{hr} \\
\text { (gal/min) }\end{array}$ & $\begin{array}{c}76 \\
(0.33)\end{array}$ & $\begin{array}{c}35 \\
(0.15)\end{array}$ & $\begin{array}{c}143 \\
(0.63)\end{array}$ & $\begin{array}{c}175 \\
(0.77)\end{array}$ & $\begin{array}{c}125 \\
(0.55)\end{array}$ \\
\hline $\begin{array}{l}\text { Input } \\
\text { events/yr }\end{array}$ & 392 & 215 & 799 & 99 & 2160 \\
$\begin{array}{l}\text { Output } \\
\text { events/yr }\end{array}$ & 388 & 215 & 808 & 98 & 1637 \\
\hline $\begin{array}{l}\text { Input annual } \\
\text { volume, liters } \\
\text { (gal) }\end{array}$ & $\begin{array}{l}20,805 \\
(5,496)\end{array}$ & $\begin{array}{c}6935 \\
(1,832)\end{array}$ & $\begin{array}{c}38,690 \\
(10,220)\end{array}$ & $\begin{array}{c}9490 \\
(2,507)\end{array}$ & $\begin{array}{c}34,675 \\
(9,160)\end{array}$ \\
$\begin{array}{l}\text { Output annual } \\
\text { volume, liters } \\
\text { (gal) }\end{array}$ & $\begin{array}{l}20,808 \\
(5,497)\end{array}$ & $\begin{array}{c}6959 \\
(1,838)\end{array}$ & $\begin{array}{c}38,692 \\
(10,221)\end{array}$ & $\begin{array}{c}9550 \\
(2,523)\end{array}$ & $\begin{array}{c}34,675 \\
(9,160)\end{array}$ \\
\hline
\end{tabular}

${ }^{\text {a }}$ Flow rates and volumes include both hot and cold water 


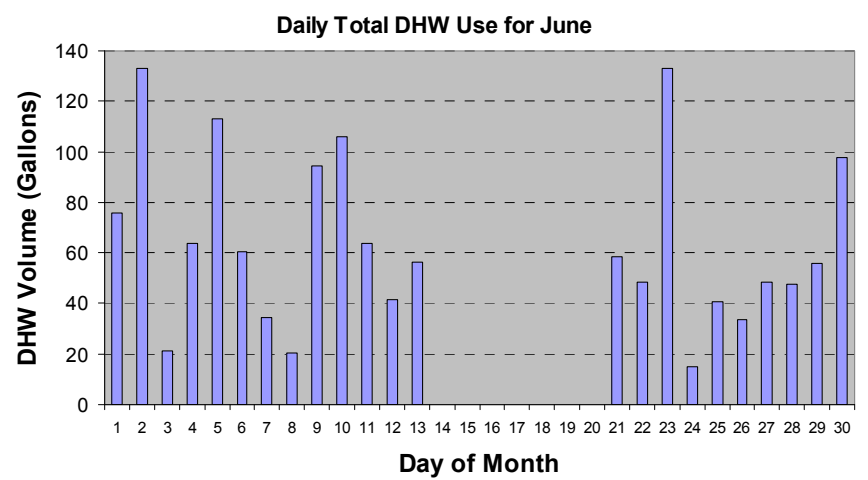

Fig. 8 Daily DHW volume for June

The normalized hourly profiles for the five DHW enduses are shown in Figs. 9 through 13. Most end-uses have a large enough number of events over the course of a year that the profiles tend to match the Benchmark hourly profiles very closely, even when the $\sigma_{\mathrm{fr}}$ is large, with relatively small differences due to random effects. End-uses with fewer events and large $\sigma_{\mathrm{fr}}$ (such as baths) do not align quite as well with the Benchmark profiles, but the correlation appears to be reasonable for our purpose.

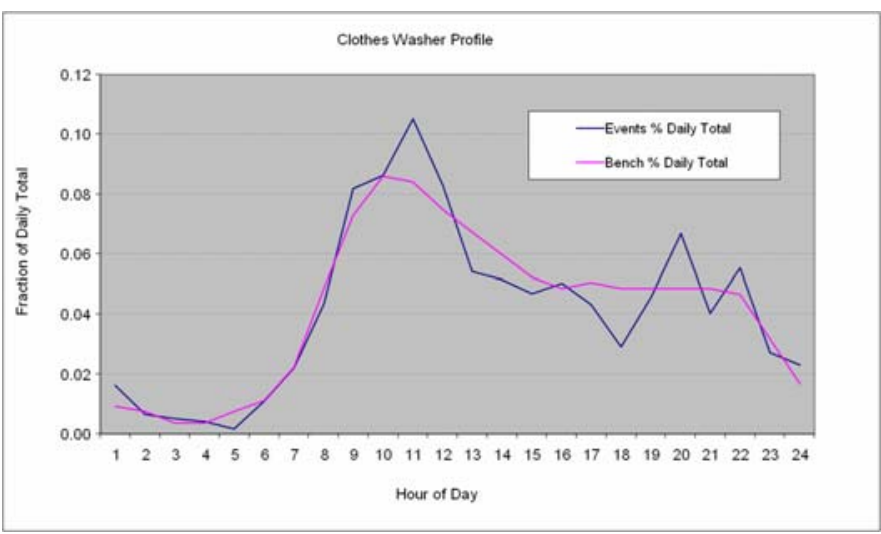

Fig. 9 Average DHW hourly profile for clothes washer events compared to Benchmark

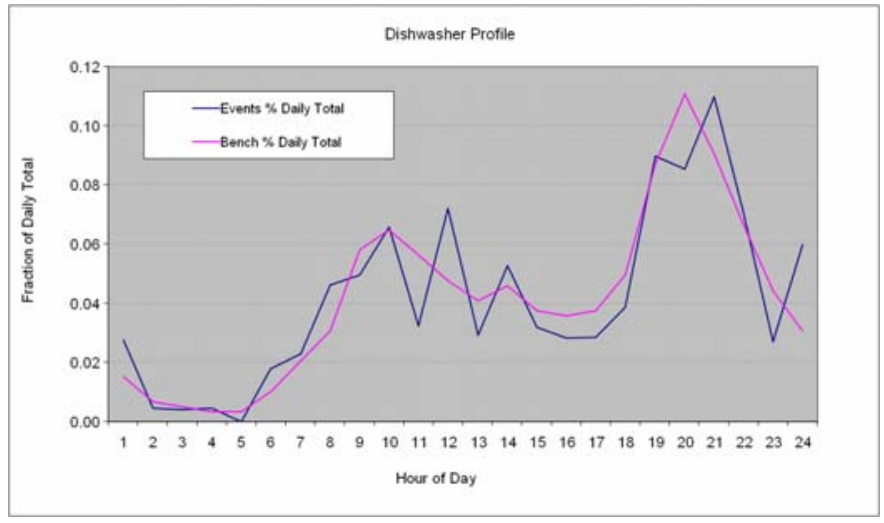

Fig. 10 Average DHW hourly profile for dishwasher events compared to Benchmark

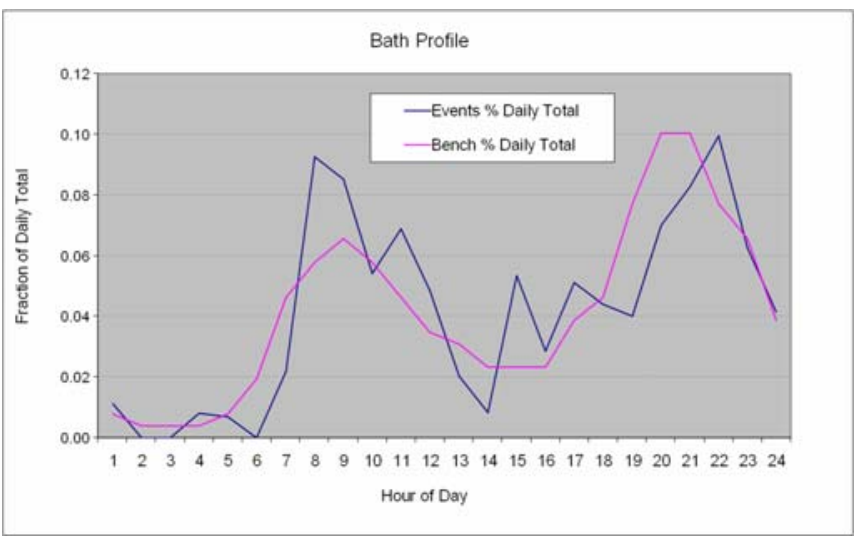

Fig. 11 Average DHW hourly profile for bath events compared to Benchmark

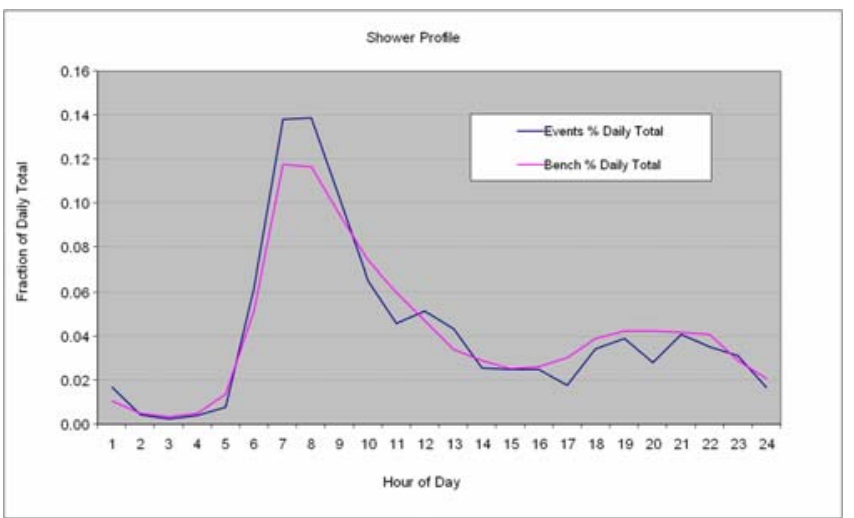

Fig. 12 Average DHW hourly profile for shower events compared to Benchmark

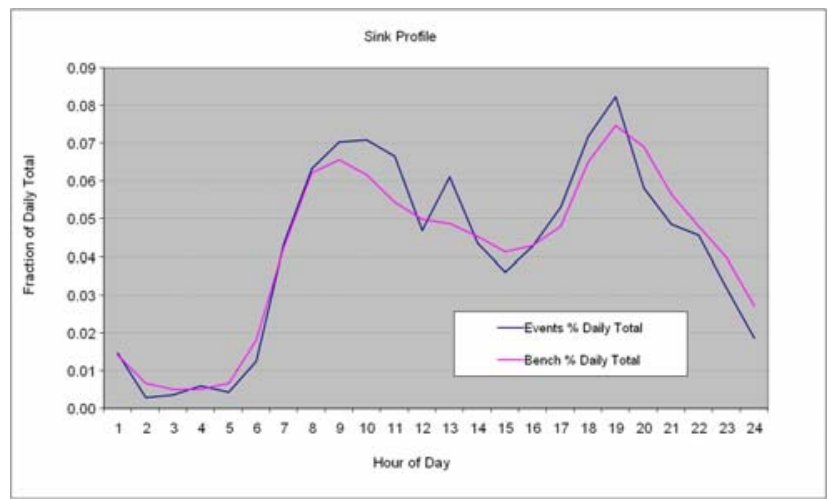

Fig. 13 Average DHW hourly profile for sink events compared to Benchmark

\section{Limitations}

While the approach described in this paper has helped to standardize the analysis of hot water systems in advanced residential buildings, there are some limitations to its application.

- The use of 6-min time-steps limits the usefulness of the event schedules for accurate predictions of distribution losses because unclustered sink events of 
1-min or less are common, and can have a significant influence on the heat losses from distribution pipes.

- For distribution systems other than the standard trunk-and-branch system assumed for the Benchmark, realistic events may be quite different depending on the magnitude of distribution losses, the presence of a recirculation loop, and the volume of stagnant water between individual fixtures and the nearest reservoir of hot water. Decreases in water usage but increases in energy usage are expected from the use of recirculation systems.

- ENERGY STAR or other non-standard appliances may consume a very different amount of hot water for washing dishes or clothes, depending on their efficiencies and control strategies.

- Day-to-day variations were designed to be consistent with a typical family and were not intended to represent differences among specific households.

- We did not address conditional probability effects, such as the fact that once some number of bath or shower events occur (e.g., four showers for a house with four people), the likelihood of more drops off. Clothes washer events would be the opposite, because they tend to be clustered in real households. Once a clothes washer event occurs, the likelihood is higher that another will follow. The model treats the event probabilities at each time step as independent of the periods before and after, which is not completely realistic.

Because it is impossible to envision all the scenarios for advanced systems, analysts must make appropriate adjustments to the event schedules based on engineering judgment. NREL is currently developing techniques to make this process more convenient and consistent.

\section{CONCLUSIONS}

NREL has developed a series of event schedules in 6-min time steps for the five major residential hot water end-uses (sinks, showers, baths, clothes washer, and dishwasher). These event schedules were designed for use in conjunction with the Building America Benchmark, and offer the opportunity for significant improvements in the consistency and accuracy of energy analysis for certain advanced residential hot water systems, including recirculation loops, tankless water heaters, and solar hot water systems with demand-side heat exchangers.

\section{ACKNOWLEDGMENTS}

The authors express our appreciation to Ren Anderson, Craig Christensen, Dennis Barley, Ali Jalalzadeh, and Mark Eastment of NREL, along with Ed Hancock of the Mountain Energy Partnership for providing very constructive insights throughout the process of developing these event schedules. We also want to thank Ed Pollock and George James of DOE for the leadership and resources necessary to perform this work.

\section{REFERENCES}

[1] R. Hendron, 2006, "Building America Research Benchmark Definition, Updated December 15, 2006," NREL/TP-550-40968, Golden, CO: National Renewable Energy Laboratory.

[2] R. Pratt, C. Conner, E. Richman, K. Ritland, W. Sandusky, and M. Taylor, 1989, "Description of Electric Energy Use in Single-Family Residences in the Pacific Northwest - End-Use Load and Consumer Assessment Program (ELCAP)," DOE/BP-13795-21, Richland, WA: Pacific Northwest National Laboratory.

[3] A. Lowenstein, and C. Hiller, 1996, "Disaggregating Residential Hot Water Use," ASHRAE Transaction Symposia, January 1996, Atlanta, GA: ASHRAE.

[4] American Society of Heating, Refrigerating, and AirConditioning Engineers (ASHRAE), 2003, HVAC Applications Handbook, Chapter 49, Atlanta, GA: ASHRAE.

[5] J.H. Davidson, S.C. Mantell, F.A. Kulacki, W. Liu, and Wu, C., 2002, "Mechanical and Thermal Performance of Polymer Heat Exchangers for Solar Hot Water," Heat Transfer 2002, Proceedings of the 12th International Heat Transfer Conference, pp. 357-362.

[6] Gary Klein, 2004, "Hot Water Distribution Systems: Part 2," Plumbing Systems and Design, May/June 2004.

[7] D. Abrams, and C. Hiller, 2000, "WATSMPL 2.0 User's Manual: Simplified Energy and Operating Cost Analysis of Storage Water Heaters," Palo Alto, CA: EPRI, (The WATSMPL 2.0 program is presently available from C. Hiller, Applied Energy Technologies, Palo Alto, CA, U.S.A.)

[8] U.S. Department of Energy (DOE), 1998, "Code of Federal Regulations Title 10, Energy, Part 430 Subpart B, Appendix E - Uniform Test Method for Measuring the Energy Consumption of Water Heaters," Washington, D.C.: U.S. Department of Energy.

[9] Solar Rating and Certification Corporation (SRCC), 2002, "SRCC Document OG-300: Operating guidelines and Minimum Standards for Certifying Solar Water Heating Systems," (www.solarrating.org/standards/ogdocuments/OG300SEP02.pdf) Cocoa, FL: Solar Rating and Certification Corporation.

[10] P. Fairey, and D. Parker, 2004, "A Review of Hot Water Draw Profiles Used in Performance Analysis of Residential Domestic Hot Water Systems," FSEC-RR56-04, Cocoa, FL: Florida Solar Energy Center.

[11] C. Christensen, G. Barker, J. Thornton, 2000, "Parametric Study of Thermal Performance of Integral Collector-Storage Solar Water Heaters," CampbellHowe, R., ed. Proceedings of the Solar 2000 Conference including Proceedings of ASES Annual Conference and Proceedings of the 25th National Passive Solar Conference, 16-21 June 2000, Madison, Wisconsin. Boulder, CO: American Solar Energy Society; Washington, DC: American Institute of Architects Committee on the Environment 6 pp.; NREL Report No. CP-550-28043.

[12] J. Burch, and J. Salasovich, 2002, "Flow Rates and Draw Variability in Solar Domestic Hot Water Usage," 
Proceedings of the Solar 2002 Conference Including Proceedings of the 31 st ASES Annual Conference and Proceedings of the 27th National Passive Solar Conference, 15-20 June 2002, Reno, Nevada. Boulder, CO: American Solar Energy Society, Inc. (ASES); pp. 287-292; NREL Report No. CP-550-31779.

[13] Davis Energy Group, 2005, HWsim Release Beta 0.202, Davis, CA: Davis Energy Group.

[14] C.C. Hiller, A.I. Lowenstein, R.L. Merriam. 1994. "Detailed Water Heater Model", ASHRAE Transactions: Symposia, 1994, pp. 948-955. Atlanta, GA: American Society of Heating, Refrigerating and Air Conditioning Engineers.

[15] C.C. Hiller, 1998, "New Hot Water Consumption Analysis and Water-Heating System Sizing Methodology," Proc. ASHRAE Transactions, 1998, p 1864-1877. Atlanta, GA: American Society of Heating, Refrigerating and Air Conditioning Engineers.

[16] U.S. Department of Energy, 2001, Residential Energy Consumption Survey, Washington, D.C.: U.S. Department of Energy.

[17] J. Lutz, G. Klein, D. Springer, and B. Howard, 2002, "Residential Hot Water Distribution Systems: Roundtable Session," presented at 2002 ACEEE Summer Study on Energy Efficiency in Buildings. Asilomar, CA: ACEEE.

[18] U.S. Department of Energy. 2001. Electronic RECS 1999, Beta Version 3.1, based on the 1997 RECS. Washington, D.C.: U.S. Department of Energy.

[19] M. Pinckard, R. Brown, J. Lutz, E. Mills, M. Moezzi, and C. Atkinson. 2003. Documentation of Calculation Methodology and Input Data for the Home Energy Saver Web Site. Berkeley, CA: Lawrence Berkeley National Laboratory.

[20] J. Holton, 2002, "Base Loads (Lighting, Appliances, DHW) and the High Performance House)," ASHRAE Transactions.

[21] T. Wenzel, J. Kooney, G. Rosenquist, M. Sanchez, and J. Hanford, 1997, Energy Data Sourcebook for the U.S. Residential Sector, LBL-40297, Berkeley, CA: Lawrence Berkeley National Laboratory.

[22] California Energy Commission (CEC), 2002, "2005 California Building Energy Efficiency Standards: Measure Analysis and Life-Cycle Cost, Part I," P40002-011, Sacramento, CA: California Energy Commission.

[23] B.R. Becker, and K.E. Stogsdill, 1990, "Development of Hot Water Use Data Base," ASHRAE Transactions, Vol. 96, Part 2, pp. 422-427, Atlanta, GA: American Society of Heating, Refrigerating and Air Conditioning Engineers.

[24] U. Jordan, and K. Vajen, 2001, "Realistic Domestic Hot-Water Profiles in Different Time Scales," Marburg, Germany: Universität Marburg.

[25] P. Mayer, and W. DeOreo, 1999, "Residential End Uses of Water," Prepared for the American Water Works Association (AWWA), Boulder, CO: Aquacraft, Inc.

[26] National Renewable Energy Laboratory (NREL), 1995, "User's Manual for TMY2s," http://rredc.nrel.gov/solar/pubs/tmy2/, Golden, CO: National Renewable Energy Laboratory.

[27] U.S. Department of Energy, 1999, "Energy Conservation Program for Consumer Products: Test Procedure for Dishwashers," Code of Federal Regulations Title 10, Energy, Part 430, Subpart B, Washington, D.C.: U.S. Department of Energy.

[28] U.S. Department of Energy, 1999, Energy Conservation Program for Consumer Products: Test Procedure for Clothes Washers. Code of Federal Regulations Title 10, Energy, Part 430, Subpart B, Washington, D.C.: U.S. Department of Energy. 


\section{REPORT DOCUMENTATION PAGE}

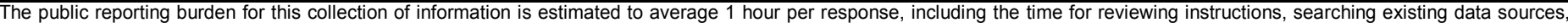

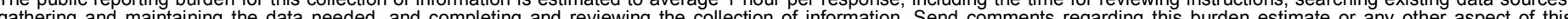

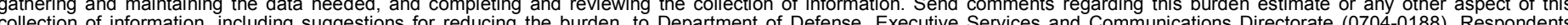

should be aware that notwithstanding any other provision of law, no person shall be subject to any penalty for failing to

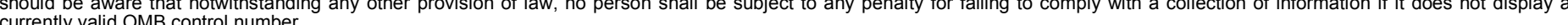

PLEASE DO NOT RETURN YOUR FORM TO THE ABOVE ORGANIZATION.

\begin{tabular}{l|l|l|l} 
1. REPORT DATE $(D D-M M-Y Y Y Y)$ & 2. & REPORT TYPE & 3. DATES COVERED (FrOm - TO)
\end{tabular}

August 2008

Conference Paper

4. TITLE AND SUBTITLE

Development of Standardized Domestic Hot Water Event Schedules

for Residential Buildings

5a. CONTRACT NUMBER

DE-AC36-99-GO10337

5b. GRANT NUMBER

5c. PROGRAM ELEMENT NUMBER

6. AUTHOR(S)

R. Hendron and J. Burch

5d. PROJECT NUMBER

NREL/CP-550-40874

5e. TASK NUMBER

BET88004

5f. WORK UNIT NUMBER
7. PERFORMING ORGANIZATION NAME(S) AND ADDRESS(ES)

National Renewable Energy Laboratory

1617 Cole Blvd.

Golden, CO 80401-3393
8. PERFORMING ORGANIZATION REPORT NUMBER

NREL/CP-550-40874

9. SPONSORING/MONITORING AGENCY NAME(S) AND ADDRESS(ES)

10. SPONSOR/MONITOR'S ACRONYM(S) NREL

11. SPONSORING/MONITORING AGENCY REPORT NUMBER

12. DISTRIBUTION AVAILABILITY STATEMENT

National Technical Information Service

U.S. Department of Commerce

5285 Port Royal Road

Springfield, VA 22161

13. SUPPLEMENTARY NOTES

14. ABSTRACT (Maximum 200 Words)

The Building America Research Benchmark is a standard house definition created as a point of reference for tracking progress toward multi-year energy savings targets. As part of its development, the National Renewable Energy Laboratory has established a set of domestic hot water events to be used in conjunction with sub-hourly analysis of advanced hot water systems.

15. SUBJECT TERMS

domestic hot water; zero energy home; building america

16. SECURITY CLASSIFICATION OF:
\begin{tabular}{|l|l|l|}
\hline $\begin{array}{l}\text { a. REPORT } \\
\text { Unclassified }\end{array}$ & $\begin{array}{c}\text { b. ABSTRACT } \\
\text { Unclassified }\end{array}$ & $\begin{array}{c}\text { c. THIS PAGE } \\
\text { Unclassified }\end{array}$ \\
\hline
\end{tabular}

\begin{tabular}{l|l|} 
17. LIMITATION & 18. \\
OF ABSTRACT & OF PAGES \\
UL & \\
\end{tabular}

19a. NAME OF RESPONSIBLE PERSON

19b. TELEPHONE NUMBER (Include area code) 